\title{
The Homeric poems in Romanian attire. A diachronic analysis (I)
}

\author{
Petre Gheorghe Bârlea* \\ Faculty of Letters, “Ovidius” University, Aleea Universității 1, 900472 Constanța, Romania
}

\section{Article info \\ History: \\ Key words: \\ translation \\ language contact \\ diachrony \\ philology \\ literary language}

Received March 14, 2015

Accepted March 22, 2015

Published July 17, 2015

\begin{abstract}
The present study examines the history of the Romanian translations of the Homeric poems, from the perspective of the evolution of Romanian literary language. We start from the premise that any such translation represents a test of virtuosity not only for the particular translator, but also for the respective modern language and culture, therefore we find it interesting to study the manner in which the development of Homeric exegesis and of translation theories parallel the phases of evolution in modern languages. Therefore the analytical framework will include principles, methods and instruments operating in such domains as language history, translation studies, as well as elements borrowed from contrastive-typological grammar, from philology, in the restrictive sense of the concept, from the theory of mentalities, cultural history and others. Our undertaking highlights the fact that the historical evolution of the act of translation is, naturally, marked by the translator's personality (theoretical and ideological options, as well as linguistic competences, poetic flair), but also by the cultural context of the respective age and space. At least in the case of Romanian culture, it is noteworthy that, on the whole, the most recent version is also the best.
\end{abstract}

\section{Introduction}

\subsection{Premises}

Any translation represents a challenge and a validation of the compensatory virtues of the target language but the translation of humanity's great literary creations constitute the supreme test, never definitely final ${ }^{1}$, of the virtues of an idiom, a test naturally marked by one's assuming responsibility towards the two languages, cultures and civilizations brought into contact. In this respect, we maintain the statement formulated in various other contexts that such and effort is perfectly comparable with that of the original creation in the language of a people (Bârlea, 2014, p. 27).

In the modern history of philosophy, translations from Homer are considered a paradigm of the manifestation of the so-called "procedures of control and delimitation of the discourse", which dominate the entire existence of the world's civilizations. Translations represent an internal procedure by which a foundational text exerts its power over other texts continually produced in the course of time. The principle of classification, ordering and distribution by which the respective procedure is actualised is called "commentary" by Michel Foucault: a discourse which "is told", which means it is stable, eternal, well individualized, generates discourses "being told", therefore seen as changing, temporary, heterogeneous ${ }^{2}$. The retelling of the Homeric text in diverse languages is a typical example of commentary, i.e., one of

\footnotetext{
*Email address: gbarlea@yahoo.fr.

${ }^{1}$ It is generally considered that any masterpiece of world literature should be re-translated in modern languages at least every two generations of readers, cf. Slușanschi, Postface to DS-I, p. 505.

2 "Commentary" primarily means, even in the terminology of M. Foucault, the continuing exegeses of the texts, as well as, at the other extremity, the original creations based on Homeric literary themes, motifs and techniques, such as the novel Ulysses by James Joyce.
} 
Petre Gheorghe Bârlea

re-interpretation, renewed in a vast array of diachronic, diatopic and diastratic variants. It is in the same conditions that the principle of the "rarefying of the text" or "the author's principle" functions as well, being complementary to the former, also paradigmatically illustrated by the Homeric texts, since they bring into discussion the relation uniqueness/multitude, with regard to the initial form of the text, and implicitly to the paternity of the discourses of primary/secondary type (Foucault, 1998, p. 23-26).

\subsection{The working material}

Our analysis centres on the "great" editions of the fundamental Homeric texts ${ }^{3}$ - the Iliad and the Odys$s e y^{4}$, that is, on the most complete and finalised versions (by the translator or the editors), or, in this sense, even considered as definitive. More specifically, we have taken into consideration the Romanian texts published between 1837 and 2012, which we divided elsewhere (Bârlea, 2014, p. 27), into three great epochs, according to the two criteria of analysis-of the evolution of the Romanian language and of the translation options.

a) The $19^{\text {th }}$ century, that of the beginnings of translation and the crystallization of modern Romanian literary language. The Iliad, I-VI, belongs to this period, translated in prose by C. Aristia and printed by I. Heliade Rădulescu, in Bucharest, in 1837 (CA-I), as does the Odyssey, in the versified version of I. Caragiani, printed in Iaşi in 1876, together with Batrachomiomachia (IC-O).

b) The $20^{\text {th }}$ century, that of the diversity of translated forms (prose, original poetry, modern poetry, free verse), of the great ventures in the usage of the Romanian language (standardized literary Romanian, autochtonization, Latinization, archaic, popular, religious, neological stock), of competition and debate on Romanian achievements and the ensuing revisions. The age is illustrated in the first place by the long-standing and widely recognised activity of G. Murnu, who gives a version of the Iliad in original hexametres in 1920, rewarded with a Romanian Academy award (GM-I), and who devoted almost a century of scholarly service in the realm of the Homeric texts, since between 1900 and 1995 there appeared scores of fragments which he published in reviews or collective volumes, partial or complete editions, with revisions, annotations and studies belonging to the author or to some great personalities, including in two definitive editions, cared by D.M. Pippidi (GMD-I in 1967 and GM-Od in 1971) and two "final version" editions, cared by L. Franga (GMF $-\mathrm{I}$ in 1985 and $\mathrm{GMF}_{2}-\mathrm{I}$ in 1995). The "Homerid poet" marked so powerfully the space of Romanian Homerology that throughout the century there were no editions of other versions of large dimensions, although the criticisms were almost as intense as the high praise received by the great translator. There were, however, four different translation from the Odyssey, signed by G. Coşbuc (1902-1918, in modern verse, published integrally as late as 1966, by I. Sfetea and Șt. Cazimir, GC-O); the same G. Murnu (1924, in blank verse, significantly revised in 1940); C. Papacostea (1929, in dactilic hexametre, only the first 12 cantos, reedited in 2013 by I. Costa, CP-O); E. Lovinescu (EL-Or1, 1935, a translation in prose, with numerous reeditations: $\mathrm{EL}-\mathrm{O}, \mathrm{EL}-\mathrm{Or} 2, \mathrm{EL}-\mathrm{Or} 3$ ).

c) The end of the $20^{\text {th }}$ century and the beginning of the $21^{\text {st }}$ century represent the age of postand post-post-modernism even in the sphere of translations. The new translators have benefited from the great exegeses and from the worldwide academic editions of the past fifty years. In this period there appeared the first Romanian prose translation of the Iliad, by R. Hâncu and S. Diamantescu (1981, HD-I, reedited under the sole authorship of R. Hâncu in 2011, RH-I), as

\footnotetext{
${ }^{3}$ The other texts attributed to Homer, such as Margites, Batrachomiomachia, The Hymns, have been translated less precisely because they do not live up to the artistic value of the two great poems. The Homeric apocryphal texts, the paternity of the two poems and the personality of Homer himself constitute what in specialist philological research is called the 'Homeric problem', cf. Marinescu-Himu \& Piatkowski, 1972, p. 54-58.

${ }^{4}$ For the spelling of the title of the second Homeric epic, we have opted for the form naturalised in Romanian philologywith $s$ and $e e[$ Odiseea].
} 
well as the complete translations ${ }^{5}$ of both poems in dactilic catelectic hexametre by D. Slușanschi (the Odyssey ${ }^{6}, 1997 / 2012$; the Iliad, 2009/2012).

We have not considered the so-called "experimental", fragmentary versions, not only quite numerous in the diachrony of Romanian Homeric studies, but also captivating, in so far as they are often owed to some personalities who have fully demonstrated both their erudition and talent ${ }^{7}$. Whether preceding or succeeding the editions of reference selected here, they will be mentioned only in relation with certain linguistic particularities, when they will be deemed to offer variants and solutions of interest to the problems under discussion. The reasons for ignoring their history are easy to understand: the space constraints of the present exposition would not have permitted any further elaboration. Our attention has focused on the versions of reference in Romanian culture: four translations from the Iliad and six translations from the Odyssey-realised in the course of 172 years of evolution of the Romanian literary language.

\subsection{The working method}

Our framework of analysis consists preponderantly of lexical-semantic items, with reference to general lexical matters, but with a special focus on onomastic items (mythonymy, anthroponymy, toponymy, etc.) and on some terminological areas such as phytonyms and animal names, anatomical terms, names designating diverse types of human and divine hierarchies, etc. Then we examine how this whole material is structured grammatically, by certain morphological and syntactical choices, from a contrastivetypological perspective. The phonetic aspect of these lexical-grammatical and stylistic structures will be analysed only there where the choice is conspicuously deliberate. The expressive forms will be examined at micro-textual and macro-textual levels, from the selection, with an ostensibly stylistic intent, of a term, a phrase or a rhyme, to the more general compositional structures-scenes, episodes, cantos, great thematic sequences. The manner of discursive transposition-prose, verse (original-ancient, medieval, modern) which justifies to a large extent this whole series of lexical-grammatical choices, will be analysed in a separate section as well, following the other levels of the writing, because these formulx constitute an independent aspect of the evolution of a language, in its literary variant. Anyway, it is evident that each linguistic compartment determines all the other ones, as the nucleus resides in the lexical-semantic options, and that the order of our approaches will not remain fixed, but will be adapted to the most poignant characteristics of each version studied. To sum up, what the translator proposes to render is first of all the "atmosphere", the spirit of the Homeric world-with its concrete, spatial and temporal conditionings, elements of realia, specific mentalities and manner of communication, all recast into the new ethnolinguistic matrix by means of words.

Practically, this suigeneris analytical framework (which makes no claim to attain either absolute rigourosity or exhaustiveness) will be applied according to the chronological criterion-phases of the translation, the temporal order of the appearence of Romanian versions-corroborated with the evolution of the Romanian language and translation techniques and coupled with the structural criterion, impused by the phonological, lexical-semantic, grammatical and stylistic aspects which significantly define each text under analysis.

Our analysis is based on the parallel treatment of four fragments we consider representative ${ }^{8}$ for the

\footnotetext{
${ }^{5} \mathrm{~A}$ few verses and portions of verses, which could no longer be retrieved from the translator's archive, were completed by F. Băltăceanu, in the posthumous editions realised by the editorial team from "Humanitas" (DS-Or).

${ }^{6}$ In this case, we adopt the the orthography of the translator [Odysseia], who was very keen on this aspect. In fact, for the title chosen by each translator, we have kept the respective forms in the Bibliography.

${ }^{7}$ Interesting contributions to the history of Romanian translations from Homer were made by Iosif Kontz, Moise Nicoară, Alecu Beldiman, Gh. M. Herescu, George Seulescu, Al.I. Odobescu, M. Eminescu, Ștefan Bezdechi, N. Iorga, Constantin Balmuș and others, cf. Lascu (1974, p. 198-217), Georgescu (2005, p. 31-51).

${ }^{8}$ We must specify that the "representativeness" we refer to here is of a personal concern, strictly technical, adapted to the requirements of the analysis we propose. We do not target the celebrated passages and episodes in the reception of the Homeric texts, such as the initial invocations, the description of Achilles' shield others of this kind, although they would have certainly offered us much richer hermeneutic suggestions and material for analysis.
} 
modes of expression in the two epic poems:

a) A short episode from the Iliad, XII, 42-52 (Euforbos' fall) - for the dynamic character of the narration, with realist, descriptive, and even naturalistic elements.

b) The nature description from the Odyssey, V, 61-75 (the nymph Calypso's entering the cave) - for the lyricism of the poetic tableau.

c) The Atena-Nestor dialogue from the Odyssey, III, 329-336-for the kind of colloquial discursivity, freed from the canons of the "confrontations" of words and actions of the war scenes.

d) The depiction of the tragic end of the fight between the Thracian Peiróos and the Greek Dióres from the Iliad, IV, 517-526, resulting in the latter's death, described in crude, naturalistic tones, typical of the first Homeric poem.

In this present study, we shall only confine ourselves to the commentary of the episode mentioned above under subsection a).

Evidently, the scope of our references will expend considerably, with examples from various other passages of the Homeric texts, according to the frequency or specificity of some textual options by which each Romanian translator tried to render the idea and the word in the creation of the Greek rhapsode.

As we have already said, the fundamental criteria of our selection have been the representativity of the texts in terms of style, the typology of the modalities of narrative and literary rendering of the content of the poems (dynamic, descriptive, dialogical), but also the existence of a larger number of Romanian versions of the respective passages.

For this reason we have avoided the most famous fragments, frequently exemplified in the universal history of Homeric exegeses. As the focus of our study is the Romanian language into which the Homeric poems were transposed, we have sought out those parts from the epics which reflect the particularities in the evolution of literary Romanian, rather than the unanimously recognised beauty of a scene or speech in the original text. The fact that the first translation from the Iliad (CA-I) contains only the first six cantos compelled us to select a fragment from this part of the poem, so as to have a clear image of the evolution manifest in all the four "great" translation into Romanian. Fragment Il., XVII, 42-52 constitutes an exception from this principle, explicable not so much by the need to clarify some lexical options regarding a certain type of specific terminology_anatomic terms, already discussed within fragment a), as by the interest raised by the irreproachable compositional structure of the micro-units of the Homeric poem: preparatory dialogue - armed confrontation - the tragic end of one of the fighters - philosophical commentary ( 1 and 2 ), by comparisons and analogies regarding the life/death cycle.

The perspective remained, in principle, the same: we have explored the capacity of the Romanian language, at the diverse sub-stages during the almost two centuries of equivalation, of rendering the sourcetext both accurately and creatively.

\subsection{Specification of the terms}

In dismantling the logical units which make up the scaffolding of the Homeric poems, we make use of terms borrowed by language sciences, many of which are known to reflect synæsthesia-which at a theoretical level means partial interference-with the terminology of visual arts. One canto (rhapsody, book) of the conventional twenty-four cantos of each poem is made up of episodes, secondary actions, relatively independent, usually delimited by the transition from one mode of expression to another, but including several such modes. By a scene we understand the subdivision dominated by one or several characters or by a well-individualized action. For example, the episode of the fighting between Menelaus and Euforbos stretches over 69 of the 761 lines of Canto XVII of the Iliad, which comprises fighting scenes, death scenes, but also dialogues, short descriptions of nature and litanies-commentaries, and if we take into account the gods' interventions, the defence of the bodies/weapons of the defeated, the episode cumulates 139 verses. All these subdivisions are here referred to as tableaux-dynamic or static, if they depict different moments and different places of some actions or landscapes. They are impregnated with dialogues/speeches, asides, (short) commentaries by the rhapsode. Some of these groups, of the type 'verbal 
confrontation' or, alternatively, 'armed confrontation' and 'short commentary', are referred to, in our terminology, as a passage or a fragment of the episode. The latter term may be also used to delimit only a part of a tableau; in such situations, we make the required specification when the case arises. By logical unit we understand the concept imposed by Homeric hermeneutics-an idea, an action, etc. or a coherent grouping of concentrated information, usually within a short succession of verses or even within a single verse, according to the principle 'one idea - one verse', cf. infra, $\$ 2$. The terms utterance, sentence, verse, bemistich and others are used in the customary sense of the syntax or prosody tracts.

\section{The art of the word in the Homeric epics}

2.0. In order to understand the difficulties encountered by the Romanian translators approaching the Homeric texts, we should remember their constitutive linguistic, stylistic and prosodic characteristics. The commentators of the Romanian translations have taken into consideration, with the exception of academic tracts or university course-books, only some of these particularities. Each exegete focused his attention on what he considered as more interesting or what seemed relevant to the level of scientific information at the time. What was, however, very well-known ever since Antiquity, actually, is that the three great aspectual categories of formal poetics-language, style, prosody-have to be analysed together, as their interconditioning had been manifest ever since the first versions of the epics under discussion. They make up an ideal poetical language, unattested concretely as characteristic of any community of real speakers, and therefore called "Homeric language" or "Homeric Greek". This is one fact that translators into modern languages had to take into account.

2.1. Of course, the various components of this special idiom came from the language spoken by the populations of the Homeric world at the dawn of that historical age. In principle, the lexical stock is archaic ionic, impregnated with aolic elements and with other diverse dialectal variants ${ }^{9}$. If we consider that ever since the Antiquity editors tampered with the texts, some in order to replace archaisms with more evolved forms (the introduction of the augment or the elimination of the dual number, for instance) ${ }^{10}$, while others, conversely, in order to restore the archaic character of the language, we can understand why modern-day translators resort to contradictory solutions in the course of the same epic episode transposed into the respective national language.

2.2. Returning to the primal epochs of the genesis of the epics, those of the "obscure centuries", a second reality that had to be taken into account is the necessity of casting this heterogeneous lexical material into the metrical pattern already consecrated as early as the Mycenæan period, namely into the catalectic dactilic hexametre. This requires the selection of a certain word from a synonymic series or from a semantic field, but also a certain dialectal, functional or other form of the respective term - preferably with a dactylic aspect (two long syllables and a short one) or, in any case, with a precise number of syllables, with a stable succession of the vowels and consonants, with artful combinations of the sounds (close, open, sonorant, liquid, trill etc.).

\footnotetext{
${ }^{9}$ We focus on the versions established in writing, base on the ancient and medieval manuscript copies, whose filiations can be chronologically reconstituted back to the post-Alexandrine vulgates, cf. Marinescu-Himu \& Piatkowski (1972, p. 103).

${ }^{10}$ Of the philologists of Alexandria and Pergamon, who contributed decisively to the establishing of some "editable" versions, Aristarh of Samothrace (216-144 a. C.) is the one who "brushed" most assiduously the old texts, namely the ones transmitted from the $7^{\text {th }}$ and $6^{\text {th }}$ centuries a.C. Having taken over the directorship of the Library of Alexandria from Aristophanes of Byzantium, he also continued the latter's work of corrector of the Homeric works. In his edition-regarded as a text of reference ever since-he systematically chose, by applying the anaphoric principle, the semantically clear word instead of polysemantic or obscure ones, due to their archaic quality, of metaphorical charge etc., he privileged the word attested by lexicographers, but also by the living language, and used accents, graphic signs for quantity, prosodic signs which better explained the lexical-semantic selection.
} 
Petre Gheorghe Bârlea

2.3. From hence ensues a third aspect of the Homeric language: the quantitative alternances of the segments of the dactylic verse with six metrical feet determines not only phonological-lexical selections, but also phonological-morphological, word order or syntactical ones. The long of short form of a verb, the contraction of a noun or pronoun, the preference for certain structural phrases, the use of parataxis in the subordination or coordination relations or, conversely, the placement of a redundant connector where the rhythm requires, all these contribute to the fashioning of the Homeric epic verse.

2.4. Furthermore, the fourth great group of techniques generating the Homeric verse regards the pauses with "resonant" effect, the repetitions engendering the well-known cliché-epithets and the formulaic system of the pattern sentences (incipits, endings of logical-syntactic units, phatic formulæ or reiterations). Modern translators frequently invoke this aspect of the Greek heroic verse, known in Homeric studies as "formulaic epic system". The first subcategory comprises: a) attributive phrases of the type "the light-footed one" (Achilles), sometimes rendered as "hawk-like Achilles", "swift-footed Achilles"; "the world's quake" (Poseidon); b) fixed phrases such as forms of address, urges ("Ares, tu, crîncene, biciul orașelor, pacostea lumii/Ares, you fierce one, the scourge of cities, the world's plight"), descriptions of typical situations ("Cade pe loc, răbufnind și zuruie-arama pe dînsul/He falls right there, grunting, the copper clinking on him”), ample syntactic concatenations, spiralling or concentrical ("Astfel grăi, și zîmbit-a zeița cu ochi verzi, Athena,/Și-l mîngîie cu-a ei mînă - la trup semănînd cu-o femeie/’Naltă, frumoasă și mult știutoare de mari meșteșuguri” [Thus spake and smiled the green-eyed goddess, Athena,/And stroked him with her hand - her body like a woman's/Tall, beautiful and well-versed in great artistry] (DS-Or, XIII, 287289). Cf. also "După ce glia ascunse și neamul acesta de oameni” [After the earth also covered this breed of people], Hesiod, Munci și zile / Works and Days, v. 135 și 151, trad. Șt. Bezdechi); c) rendering certain actions or presenting certain objects, garments, rituals, etc. by groups of verses, supposed to constitute a unit, even if within the canto they represent parentheses, supplementary interventions-namely, those retardationes, specific to the Iliad in particular.

2.5. The fifth level is situated at a more subtle and, consequently, more difficult layer of the correspondence between "the ideational plane and that of expression" (Marinescu-Himu \& Piatkowski, 1972, p. 105). No matter if the succession of the constitutive parts was based on symmetry or an opposition, on an ample simile or an extended metaphor, allegory etc., the rhapsode strove to make an idea fit comfortably and poignantly in one verse, one dyptic or, in any case, in a well-defined group of hexametres. Of course, in each poem there are sufficient examples of logical and expressive micro-compositional discordances, even after the eliminations practised during the oral phase of circulation of the Homeric epics and especially during the phase of academic corrections from the period of their distillation into writing and of the scholarly editions-Alexandrine and post-Alexandrine. But the aspiration for perfection is evident: each hexametre seeks to represent a profound idea, a lofty sentiment, with an inexpugnable internal logic, all cast into a brilliant form, perfectly suited to the nature of the content. Then, each hexametre polished in this way must be integrated without fail into the entire episode, canto and thus into the poem as a whole. The final result is meant to be a masterpiece of textual architecture accommodating a treasure of ancient thought and sensibility, whose value continued to increase through time.

2.6. This brings us to the sixth level of Homeric artistry-that of the macro-structures. The two poems are thematically interrelated, but represent different perspectives on the legendary Trojan War, which means, according to present-day terminology, two different subjects. These, in their turn, represent different epochs (reflected as such in the actual genesis of the poems), different mentalities and, ultimately, different compositional structures and poetic techniques. The Iliad is a compositional dyptic, consecrated to the two fundamental themes, the "anger" of Achilles and the "will" of Zeus. The linear, asynchronous plot is dominated by heroic characters and by gods (almost in equal proportion), with dynamism and rhetoricism as main characteristics. The Odyssey is a circular triptych devoted to the nostos ("return") of Odysseus and 
made up of a) Telemachy-Telemachus' journey in search of knowledge of father; b) the wanderings of Odysseus (the nòstos proper); c) the return to Ithaca, with all the expected surprises, the plot unfolding on several parallel planes, either simultaneously or according to a particular logic of the chronological sequence and a convergent final point, factual and dialogical at the same time-mnesterophonia "the killing of the suitors". The compositional techniques are more varied-dramatic, narrative, descriptive-, while the similes, metaphors and allegories are more numerous and more subtle in the second epic ${ }^{11}$. The lexical and semantic material, the grammatical and stylistic structures are constantly adapted to these discursive methods, techniques and strategies, changing in accordance to the manner they are supposed to fit within the pattern of the catalectic dactylic hexametre.

2.7. These constraints operated for the text of ancient poems, alongside, however, the liberty of the rhapsodes of finding on the spot the word or form they thought more fit to express the idea. In the translators' case, there emerges a level of further constraints, that imposed by the fidelity towards the source-text. In principle, translating into a foreign language means the conversion into words with precisely the same meaning, from the same functional and stylistic register and with the same grammatical forms, to the extent to which these exist in the target language. The problem of contrastive-typological differences, which already constitutes a source of great difficulty in this sense, is known to be doubled by the great problem of versification. In comparison with the Greek verse, base on the quantity of the syllables and on a melodicity obtained through the succession of the length and stress of the phonemes, combined with the effects of the voice, rhythm and pauses etc., the modern verse makes use of only two of these, in a markedly changed manner-the possible rhyme is only one of these changes.

2.8. But all these mean an endless struggle on the two fronts-of the language of the source-text, which must be fully understood in all its linguistic and contextual subtleties, as well of the language of the target-text, which has to render the respective subtleties in the most truthful and artistically poignant manner possible. The first options for the translators - for versions in prose, in ancient metre or in modern metre-would mean, from the outset, sacrificing some of the aspects enumerated above. The decision is not whether or not to do this, but how much and what exactly each translator feels compelled to sacrifice. And the struggle to re-create the poems anew in the fashion of their own languages starts only after these painful decisions to deliberately ignore some of the perceivable particularities of the original. As for the tormenting loca obscura, the problem is not even shouldered by the translators any more, now that exegesis has become a profession in its own right...

\section{The testimony of the Homeric texts}

The selection of some fragments from the Homeric texts for a linguistic analysis confirms two apparently contradictory assertions made above: a) fragmentary analyses cannot do justice to the richness and expressiveness of the Homeric idiom; b) any fragment reflects the whole, as the compositional and linguistic distillation of the poems, which has taken place slowly, in the course of centuries, conferred the poems the

\footnotetext{
${ }^{11}$ Of the memorable characterizations of the two epics, it is worth considering the one belonging to the anonymous author of the Treatise on the Sublime, who considers that the Iliad is the creation of Homer's maturity and the Odyssey of his old age. Beyond the fact that the exegets consider the time span between the two epics to be longer-of about a century, both in terms of the civilization described and of the epoch of the composition of the complete forms, which annuls the conception of the single paternity-, the observation of the Anonymous is as mistaken as it is expressive: "In the Odyssey, Homer is like the sun at dusk, which retains its grandeur, but is without strength". The Iliad, however, is a "dramatic, tempestuous poem", has a lofty style, a multitude of passions, vividness and vigour in the speeches, a wealth of images taken from the real world, incentives for great deeds. In these conditions, the Odyssey is reduced to a fairytale narrating of incredible wanderings, cf. Tratatul despre sublim, ed. C. Balmuş, 1935, p. 38-39. Still, much more profound remains the characterization made by Aristotle, also based on an opposition: the Iliad is a "simple and pathetic poem", while the Odyssey is a "complex poem" (cf. Aristotel, 1965, 1459b, 16).
} 
Petre Gheorghe Bârlea

coherence of the system, meaning that each detail evinces correspondences with other details, on an ever more comprehensive scale (tableaux, episodes, cantos), as well as with the whole at the same time, and the latter concomitantly depend on and determine the former, as in the case of a living organism.

The de-structuring operations that follow have a preponderantly methodological value, imposed by the customary procedures of linguistic analyses on a given text. The observations of a general nature are formulated, as we have shown in the section regarding the approach, in relation to the entire text of the Homeric poems.

\section{1. "Nemilostivul pietroi / The merciless stone”. The Death of Diores (Hom., Il., IV, 517-526)}

Typical for the scenes of a tragic naturalism in the Iliad, fragment Il, IV, 517-526 follows a succession of similar tableaux, which make up the epic episode of the fighting at the end Book IV, after the war is revived, due to the breach of the truce, and after Agamemnon reviews the troops. Antiphus kills Leucus, Odysseus' companion (490-493); angered by this, the latter kills Democóon, Priam's love-child (494504). The two short preliminary discourses are not lacking, though now it is only the gods who speak. First we are recounted the words of Apollo, who care emboldens the Trojans (507-514), and then the rhapsode notes briefly that, on the other side, Athena urges the Achæans to battle (515-516).

Such fragments are representative for the pre-eminently warlike nature of the world depicted in the Iliad. It conveys with frightful precision the manner in which the javelin, the spear, the arrow the sword, the mace, the rock and others pierce, break, rip off various parts of the human body, with thorough accounts of the breaking and splattering bones, tendons, organs, skin, blood. There are brief notations of the last gestures of the dying warrior, the shock of the one who had hoped to the last that fate will spare him, the pain, the horror, the indifference, the unexpected, often grotesque reactions of the victim and the victor. The despair of the victim and the vanity of the killer are expressed in scant words. The continuation then softens a little, as if to counterbalance these crude images: the brothers in arms try to drag the fallen one out of the battlefield, an enraged comrade immediately takes over the counterattack, and the victorious attacker is himself struck down by another blow, more or less incidental. The minimal lyrical interludes are never missing, in their repetitiveness, the fixed formulæ foreshadow the pall of darkness covering the eyes of the defeated one, the comparisons with natural elements (vegetal, animal) attenuates by generalization the shock of the fallen one's passing away towards the welcoming, but indifferent Universe, while the speech somehow justifies the denouement and foretells a new confrontation:

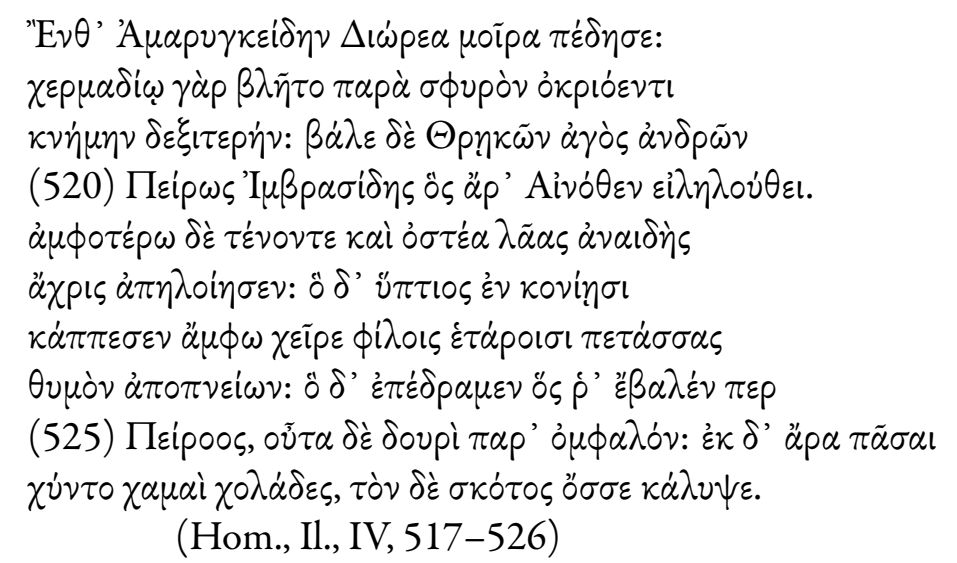

The epic thread suddenly returns to the series of crude descriptions of the heroes' death, with a brief introductory notation, which includes both the wry, neutral information and the philosophical comment on unforgiving destiny:

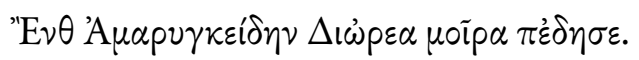

The Romanian translations are, without exception, permeated by the sobriety of the original verse: 
Aici a legat soarta p'Amarinţid Dior. (CA-I, IV, 517)

...Pe Dior, Fiul lui Amarinceu, ursita-l robi pe vecie. (GM-I, IV, 516-517)

Soarta cade năpraznic asupra lui Diòres, ful lui Amarinceu. (HD-I, IV, 517)

Dar pe Diores ${ }^{12}$ al lui Amarynkes grea soartă-l răpuse. (DS-I, IV, 517)

(Then great Diores fell, by doom divine, / In vain his valour and illustrious line.)

The interpretation does not pose any big problems, despite the synthetic enunciation. The initial term, $\ddot{\varepsilon} \nu \vartheta(\alpha)$ (a demonstrative adverb with a temporal value or a relative adverb with a spatial value) is taken as a time adverb in the version $\mathrm{CA}-\mathrm{I}$, and as an adversative coordinating conjunction in DS-I. Grammatically speaking, the translation "în acel(aşi) loc", "tot acolo" (in the same place) is more justifiable, while logically, the opposition could be made at the most with the the recent death of Democóon, a scene way behind, interrupted by the oratorical interludes. Therefore the compliant observance of the proper sense of the term with the role of incipit in the old Romanian text (1837) seems the most accurate solution.

The greater differences appear in the section about the working of destiny. As usual, G. Murnu is the most courageous innovator, adding at the end the adverbial time phrase, which CA-I had deemed more suitable at the beginning of the section, interpreting the meaning of the verb and making the entire statement longer than one verse, as the specificity of the Homeric text required (one idea - one verse; one logical unit developed in one tableau - one unitary group of verses). More concretely, the Greek phrase

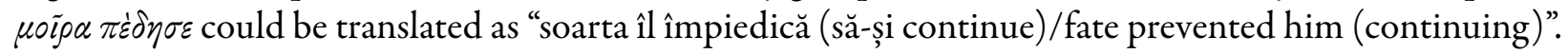
The verbs "a robi/to enchain", "a cădea (năpraznic)/to tumble", "a răpune/to strike down” are, evidently, farther from "a lega/to bind” in the original ( $\pi \dot{\varepsilon} \delta \dot{\alpha} \omega$ "leg, împiedic, înlănțui/bind, prevent, enchain”), but the additions to the verbal core help suggest more emphatically how Destiny works. This is itself designated, in general, by the term customary in standard literary Romanian, soartă/fate, with the expected search for the indigenous synonym at GM-I - ursită/doom and qualified by the epithet grea/heavy, at DS-I, which here shifts in a nominal plane the amplitude of the verbal group in the other verses.

The scene of the killing proper is interrupted only by the habitual identification of the hero-culprit, customary for such sequences. As for the rest, the mechanical and anatomic details are described in all their crudeness - coldly, callously, technically - this even with regard to the final gesture of the arms raised entreatingly, which resumes the brief notation of some restrained tokens of human compassion and reflection, discretely inserted in the initial verse, as well. We shall reproduce the entire scene in the version DS-I, perhaps the most precise, the most linguistically and stylistically nuanced, in this case:

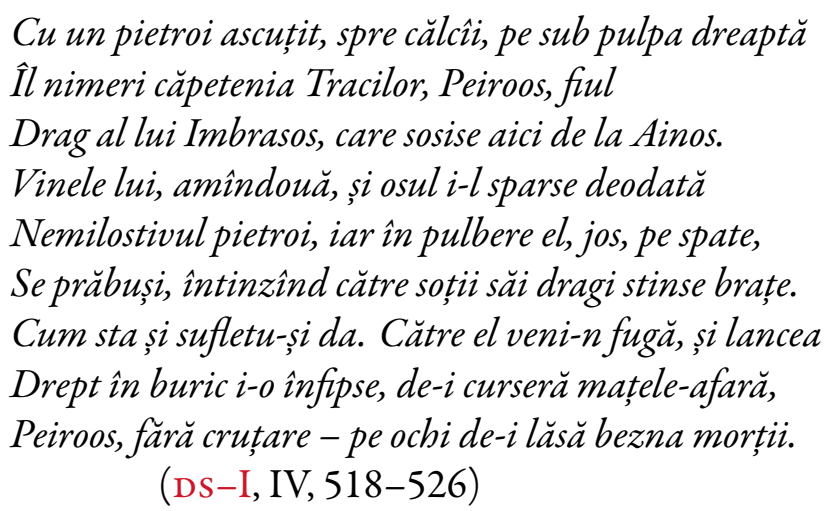

"Then was Amarynceus' son, Diores, caught in the snare of fate; for with a jagged stone was he smitten on the right leg by the ankle, and it was the leader of the Thracians that made the cast, [520] even Peiros, son of Imbrasus, that had come from Ænus. The sinews twain and the bones did the ruthless stone utterly crush; and he fell backward in the dust and stretched out both his hands to his dear comrades, gasping out his life; and there ran up he that smote him, [525] Peiros, and dealt him a wound with a thrust of his spear beside the navel; and forth upon

\footnotetext{
${ }^{12}$ In the DS-I edition (p. 84), the name is wrongly typed: Diones.
} 
the ground gushed all his bowels, and darkness enfolded his eyes." (English translation by A.T. Murray, 1924) ${ }^{\dagger}$.

In such situations, the target language and its wielder have to follow closely this terrible alternation between idiomatic fixity and lexical and grammatical creativity, in a state of tension comparable to the heroes in the scenes conveyed for readers in a new world.

The evolution of the literary Romanian language, as well as the evolution of accuracy in lexical conversions, based on an ever more scientific exegesis of the original text, can be traced, first of all, in the terminology of human anatomy. From "perve/nerves" (CA-I), to "vine/veins" (GM-I and DS-I) and then to "tendoane/tendons" (HD-I), the course of Romanian anatomical vocabulary definitely progressed, not without deviations (for the Gr. sg. $\tau \dot{\varepsilon} \nu \omega \nu$, used in the dual number). For the Greek $\tau \dot{0} \sigma \varphi v \rho o ́ s$ "gleznea/ankle" is used in the singular (CA-I), alternatively glezne/ankles (CM; DS-I); călcîi/heel (HD-I), while for ö $\mu \varphi a \lambda o ́ s$ "buric/navel", GM-I innovates, extending the semantic sphere to "pîntec/belly". For $\chi 0 \lambda \alpha ́ \delta \varepsilon \varsigma$ we have as equivalents "mațe/guts" (CA-I; DS-I) and "măruntaie/entrails" (GM-I; HD-I). In such cases, we can speak of variations of semantic equivalence in the terminological register, rather than of the translator's interpretation, as the options configure the merely technical vocabulary.

At a higher level of subjectivity regarding the selection of equivalents are the grammatical constructions of a fixed, standardized character, such as the group $\mathrm{N}+\mathrm{G}$ of descendence in the onomastic of the characters, in Romanian and other modern languages. Homer uses the customary patronymic constructions, formed by compounding, in order to identify the warriors: 'A $\mu \alpha \rho \gamma \varkappa \varepsilon i \delta \eta \varsigma \Delta \iota \omega \dot{\omega} \rho \varsigma$, Diores Amarinceul,

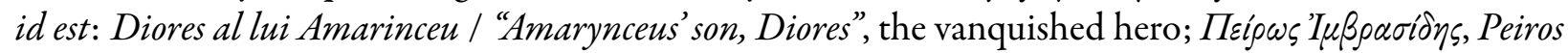
al lui Imbrasos / "Peiros, son of Imbrasus", the victorious hero, as in other hundreds of similar situations in the poem. Modern translators ${ }^{13}$ feel the need to mark the idea of filiation by the concrete term, sometimes seeking the most expressive synonym or adding a hypocoristic epithet to the denotative one. This happens even in the Romanian prose versions, where the supletive terms are not even justified by metrical or prosodic requirements, with the exception of CA-I and DS-I, but only in the case of the first name. Costache Aristia simplifies the nominal group $\mathrm{N}-\mathrm{G}$ as $\mathrm{N}-\mathrm{N}$, probable because the formula "al lui.../of the..." had seemed to him rather popular and unsuited for an epoch in which he militated for the elimination of these phrases, aimed at shaping a supra-dialectal literary language.

Amarințid Dior / Dior of Amarynceus (CA-I, IV, 517)

Diores, fu al lui Amarinceu / Dior, son of Amarynceus (GM-I, IV, 506-507)

Diores, Fiul lui Amarinceu /Dior, the Son of Amarynceus (HD-I, IV, 517/70)

Diores al lui Amarynkes /Amarynceus' diores (DS-I, IV, 517).

${ }^{\dagger}$ For an English version in verse, remarkable for its archaic flavour, but also for the Latinisation of proper names, specific to the period, we can read the text crafted by Alexander Pope between 1715 and 1720:

"A broken rock the force of Pyrus threw,

(Who from cold Ænus led the Thracian crew,)

Full on his ankle dropp'd the ponderous stone,

Burst the strong nerves, and crash'd the solid bone.

Supine he tumbles on the crimson sands,

Before his helpless friends, and native bands,

And spreads for aid his unavailing hands.

The foe rush'd furious as he pants for breath,

And through his navel drove the pointed death:

His gushing entrails smoked upon the ground,

And the warm life came issuing from the wound."

(The Iliad of Homer, translated by Alexander Pope; Il-Pope)

${ }^{13}$ We use the generic term "modern" in order to underline that it is not only the Romanian translators who work in this manner, but also the English, the French, the Serbians and others, although all modern languages have in their system of archaic and popular variants the onomastic formula based on the genitive of paternal filiation: "X of $Y$ ". 
Prințul... numit Imbracid Piros / The prince... called Piros of Imbracid (cA-I, IV, 519-520)

Răsadul lui Imbrasos, Pirus / Imbrasos' offspring, Pirus (GM-I, IV, 509)

Pèiroos, vlăstar al lui İmbrosos / Pèiroos, İmbrosos's descendent (HD-I, IV, 518/70)

Peiroos, fiul/Drag al lui Imbrasos / Peiroos, Imbrasos' Dearest/Son (DS-I, IV, 519-520)

As usual, GM-I goes very far with the lexical "invention", looking for the most marked term, even if this means valorising some archaic, dialectal words, and, as in the case of "răsad/upshot", fitting the the context only metaphorically. CA-I and DS-I also cultivate the extremes, by being either (very) faithful to the original -Dior(es) or taking explicable liberties, as shown above - Piros/Peiroos. The HD-I version would represent a certain balance between these options.

As was to be expected, the translators' explorations result in even greater variations in the phrases with an attributive epithet, from the relatively fixed formulæ constituting the quite parsimonious lyrical comments synthetically inserted into these tableaux of violent death ending the fighting scenes of the Iliad. There are at least three such formulæ in the passage analysed here, apart from the one included in the verse already quoted above, providing the induction to the scene: the victim's lifeless arms raised towards his comrades; his dying breath and, rather redundant, the darkness covering his eyes. The first of them is part of a more varied series of heart-rending gestures, profoundly human in their tragic quality and in stark contrast to the brutal description of the martial background. The other two are fixed formulx, extremely frequent throughout the entire poem. In Canto IV of the Iliad alone-one predominantly narrative, dynamic and objective- the lyrical expression of passing away is repeated over thirty times. However, it never loses its spiritual reflexive charge, so necessary not only for the rhapsode's descriptive respite, but also for the readers' capacity to cope with the overflow of crude details depicting those locked in mortal combat. The manner in which the translators render these constructions, situated between automatic verbal habits and breaks in the rhythm of naturalistic descriptions, reflect once more the evolution of the Romanian language, on the one hand, and the translator's individual qualities, on the other:
a) Căzu, și mîinile’ ambe léntinse la prieteni
b) Iși da și suflarea
c) ...s'a dus, peri Dior.
(CA-I, IV, 523-524, 526)
a) Cade Diores și brațele-ntinde spre bunii tovarăși
b) Dindu-și suflarea din urmă
c) ...pe ochi i se lasă-ntuneric.

(GM-I, IV, 513-514, 516)
a) Diòres cade pe spate și, sleit de puteri, își întinde brațele
b) spre tovarăşii săi
c) ...Iară beznele morții îi învăluie ochii
(HD-I, IV, 517-526)
a) Se prăbuşi, intinzînd către soții săi dragi stinse brațe
b) Cum sta și sufletu-şi da.
c) Peiroos... pe ochi de-i lăsă bezna morții
(Ds-I, IV, 523-524, 526).

In the Homeric text the last formula is relatively fixed, as mentioned above, and impersonal:

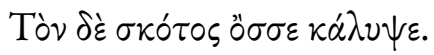

"Intunericul îi acoperă ochii” / The darkness is covering his eyes. 
C. Aristia translates the idea, but not the Homeric metaphor, since this time he uses expressions from the popular Romanian metaphoric stock: $s$-a dus, pieri / he passed away, perished. The others render the sentence faithfully enough, each of them according to the necessities of the grammatical, stylistic and prosodic constructions created in Romanian. D. Slușanschi personalises the expression, the action being attributed to Peiroos. It seems odd that R. Hâncu should skip the expression b), of all the three discussed here. Taken out of context, they seem redundant, it is true. In fact, the two phrases marking the end of Diores correspond to the two blows received from Peiroos-the first with the broken rock, the other one, decisive, with the spear. The expression ignored here is used a few verses below, though, as from the immediately following tableau we learn that Peiroos himself is mortally wounded (by the Ætolian Thoas), just as he was concentrating on ending Diores' life. Only now comes the formulation "şi viața-i curmă pe vecie/ and he ended his life forever", thus avoiding, actually, a repetition after too short a distance.

Therefore, the short scenes of mortal combat occur in rapid succession, interrupted only by the periphrases identifying the protagonists and the very concise notations regarding the end pre-ordained by destiny. Everything is well-integrated into ample tableaux, dominated by dynamism and an atrocious realism. Normally, in accordance with the symmetrically repetitive structure of the Homeric epos, there should have followed a speech—of the victor, justifying ${ }^{14}$ somehow the ending of the respective confrontation. But this time in dust lay both the great leaders-of the Thracians and of the Epeians, and "alături, mai fură uciși o mulțime/many more were dead beside" (GM-I, IV, 528). The idea of the general slaughter is resumed, actually, a few verses below, by generalization:

\section{"Droaie de-ahei și troieni căzuseră-n ziua aceea." \\ ("And crowds on crowds triumphantly expired.") \\ (GM-I, IV, 523)}

Therefore, says the rhapsode, none of the parties could have defame the valience of the others (Il., IV, 539). However, a deity speaks again, so that the compositional symmetry is twice observed-once because the opening discursive passages are present even in this fragment distinctly charged with concrete action, and once more because the speakers belong to the same world—of divine beings, in this case.

Apart from the three syntagms with a reflexive and lyrical content inserted into the objective exposition of the military exploits, there is also, however, one even more synthetically formulated, almost invisible, if its rendering had not consisted in a personifying epithet and if the Romanian translation had not caused dissymmetries in the case of the versions realised.

It is the first of the "weapons" used by Peiroos in the killing of Diòres: the jagged rock. In the original, the term occurs twice, as the synonyms $\chi \varepsilon \rho \mu \alpha \dot{\delta} \delta 0 \mathrm{~V}$ "piatră, bolovan / rock, boulder" and $\lambda \tilde{\alpha} \alpha \varsigma^{15}$ "stone".

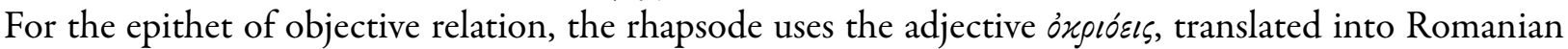
according to the evolution of the language: sgrebulos, in 1837 (CA-I), ascuțit/sharp, pointed, in 1928 and 2002 (GM-I and DS-I), colțuros / jagged, in 1980 (HD-I). The other epithet represents one of those synthetic lyrical interludes frequently occuring in the epic texture of the epic episodes in the Iliad. Replaying the initial determinant (piatră/pietroi, stone/rock), where the Greek rhapsode had avoided the repetition, the Romanian translators render this qualifying epithet äwalon's "nerușinat/shameless", which expresses a striking subjective appreciation of the situation dominated by dynamism, by "nemilostiv/merciless" (GM-I and DS-I) or "fără de milă/pitiless" (HD-I). CA seems to have doubted that the personifying epithet could have been used in that place, and therefore he ignores it, as an unacceptable lesson, preferring to repeat the first adjective, "sgrebulos". But the Greek prefixated derivative had precisely this role, of suggesting, by means of an oxymoronic personification, the merciless action of Destiny, made manifest in

\footnotetext{
${ }^{14}$ As a rule, the victor's speech refers to the unfair actions and vanity of the vanquished one, whom he succeeded in punishing, eventually, with the gods' assistance. However, the short speech is itself a vanitous cry of joy, a verbal outburst after a state of extreme tension lived in the proximity of death.

${ }^{15}$ The first term is, in fact, a diminutive from $\chi \varepsilon \rho \mu a ́ s$, designating "rock for throwing", used as a weapon during Homeric times, while the second designates the concept of "stone" in general.
} 
a rock. When the first translation by G. Murnu appeared, one of the charges formulated by Victor Eftimiu, in his famous critique of the 1928 version, targeted precisely this phrase. He, the highly refined poet, prose writer, dramatist and journalist, well-acquainted with the secrets of the connotative metaphorical uses in both the languages wielded by G. Murnu, was not willing to accept such an association, which represented no more than a banal personification, after all: "pietroi nemilostiv"? Cum, adică?/What does that mean? ${ }^{16}$.

To conclude, along the almost two centuries in the evolution of the attempts of translation into Romanian, the texts of this kind from the Iliad - characterized by an epic quality which is condensed, dynamic, naturalistic, masterfully impregnated with dialogic, descriptive elements and understated lyrical commentary, all serving a dramatic vision verging on tragedy (were it not obvious that the characters' mentality helps them perceive the facts according to their code_-of honour, heroism and faith in destiny) — for all their rigours, could well be rendered in the translators' native language due to successive explorations, which led to higher fidelity to the idea and the harsh harmony of the original. A varied vocabulary, in terms of semantic areas and stylistic registers, a rich grammar, profoundly indebted to poetic expression, poise between the amplitude of the epic development and the parsimony of of the lyrical-philosophical commentary, between the clatter of arms and the mastery of speech-all these are to be found in such passages. The archaic, popular term and the attendant grammatical construction were used in the beginning because it was all that was available to the translator. Later, the same treasure of archaic words and constructions begins to be sought after so as to render a long bygone world, even if from other geographic and spiritual spaces. The new terms, conjugated with bold creations, are likely to render the implicit nuances and suggestions constantly discovered by exegetes of the original text.

\section{Bibliography}

\section{A. Sources}

\section{A.1. Text editions}

Il-A-H-C = Homers, Ilias, edited by Ameis, K.F., Hentze, C. \& Camer, P., 2 vol. ( $\times 4$ facs), ed. 4-8, Leipzig: Teubner, 19051932. Reimpr.: Hidesheim, 1970.

Il-M-A = Homer, Iliad, edited by Monro, D. B. \& Alen, Th. W., Vol. I-II, Oxford: Clarendon Press 1924/1966²

Il-PM = Homère, Iliade, edited by P. Mazon et al., Tomes I-IV, Paris: Les Belles Lettres, 1974.

Il-Pope $=$ The Iliad of Homer, translated by Al. Pope, with notes by the Rev. Th. A. Buckley, M.A., F.S.A. and Flaxman's Designs, London, 1899 [online].

Od-Murray $=$ Homer, The Odyssey with an English Translation by A.T. Murray, PhD in two volumes, Cambridge, MA: Harvard University Press; London: William Heinemann, Ltd., 1919.

PP-I = Iliad online version from the Perseus Project (PP) translation and hyperlinks (Homeri Opera in five volumes, edited by Monro, D. B. \& Alen, Th. W., Oxford: University Press, 1920.)

$\mathrm{pp}-\mathrm{O}=$ Odyssey online version from the Perseus Project (pp) translation and hyperlinks (Homer, The Odyssey with an English Translation by A.T. Murray, PhD in two volumes. Cambridge, MA: Harvard University Press; London: William Heinemann, Ltd. 1919.).

\section{A.2. Translations into Romanian}

\section{A.2.1. Iliada / The Iliad}

CA-I = Omer, Iliada, Tome I. Cantos I-VI. Translation by C. Aristia, Bucureşti: Tipografia lui Eliad, 1837 (blank verse).

DS-I = Homer, Iliada . Translated in hexametres, with a postface, bibliography and indices by D. Sluşanschi and illustrated by

M. Coşulețu, Bucureşti: Editura Humanitas, 2012.

GM-I = Homer, Iiada. Translated in Romanian by G. Murnu. Recipient of The Great Award of the Romanian Academy,

[Bucureşti]: Cultura Națională, [1920].

GMD-I = Homer, Iliada. Translation in the original metre by G. Murnu. Introductory study and notes by D.M. Pippidi.

Definitive edition. Bucureşti: Editura pentru Literatură Universală, 1967.

$\mathrm{GMF}_{1}-\mathrm{I}=$ Homer, Iliada. Translation in the original metre by G. Murnu. Supervision, introductory study, notes and glossary

by L. Franga, Bucureşti: Editura Univers, 1985.

\footnotetext{
${ }^{16}$ Cf. Victor Eftimiu, Traducerea "Iliadei”, in: “Opere”, vol. 18, p. 249-288.

*The bibliographic references have in view the complete version of this study, which will be continued in the next issue of the journal "Diacronia".
} 
$\mathrm{GMF}_{2}-\mathrm{I}=$ Homer, Iliada. Translation in the original metre by G. Murnu. $2^{\text {nd }}$ edition, with a new introductory study, notes, preface to the edition and glossary by L. Franga, Bucureşti: Editura Fundației Culturale, 1995.

HD-I = Homer, Iliada. Translation [in prose] by R. Hâncu and S. Diamantescu. Vol. I-II, Bucureşti: Editura Minerva, 1981. RH-I = Homer, Iliada. Translation by R. Hâncu. Foreword by G. Hâncu. Bucureşti: Editura Mondoro/Editura Gramar, 2011.

\section{A.2.2. Odiseea / The Odyssey}

$\mathrm{CP}-\mathrm{O}=$ Homer, Odysseia, I-XII. Translation by C. Papacostea, 1929. Introduction, note on the edition, notes and indices by

I. Costa, Bucureşti: Editura Muzeului Literaturii Române, 2013.

DS-O = Homer, Odysseia. Translation in hexametres by D. Sluşanschi. Bucureşti: Editura Paideia, 2009.

DS-Or = Homer, Odysseia. Translation in hexametres, with postface, bibliography and indices by D. Sluşanschi and illustrated

by D. Rădvan. Revisions and completions by O. Gordon and F. Băltăceanu. Bucureşti: Editura Humanitas, 2012.

$\mathrm{EL}-\mathrm{O}=$ Homer, Odiseea . Translation in prose by E. Lovinescu. Foreword and notes by E. Mazilu-Lovinescu, Bucureşti: Editura MondoRo, 1995.

EL-Or1 = Homer, Odiseea. [Translation by E. Lovinescu. Text revised and annotated by T. Costa. Introductory study and indices by M. Nasta], Bucureşti: Editura pentru Literatură, 1963. ( $1^{\text {st }}$ ed.: 1935)

EL-Or2 = Homer, Odiseea, Vol. I-II. Translation by E. Lovinescu. Text revision and notes by T. Costa. Preface by V. Antonescu, Bucureşti: Editura Tineretului, [1966].

EL-Or3 = Homer, Odiseea . Translation by E. Lovinescu. Edition revised and postface by T. Diaconescu. Bucureşti: Saeculum I. O., 1996.

GC-O = Homer, Odiseea, vol. I-II. Translation by G. Coşbuc. Edition supervised by I. Sfetea and Şt. Cazimir. Preface by Şt. Cazimir. Bucureşti: Editura pentru Literatură, 1966. (Mss. 1916).

$\mathrm{GM}-\mathrm{O}=$ Homer, Odissea. Translation by G. Murnu. Introductory study and notes by A. Pârvulescu. Bucureşti: Editura Univers, 1979.

GM-Od = Homer, Odiseea. Translation by G. Murnu. Introductory study and notes by D.M. Pippidi. Definitive edition, Bucureşti: Editura Univers, 1971. (1 ${ }^{\text {st }}$ ed.: 1928)

IC-O = Odiseea. Batrachomyomachia - Războiul şoarecilor cu broaştele. Translation in prose, notes and prezentations by I. Caragiani. Argument. Notes on the edition by I. Acsan, Bucureşti: Editura MondoRo, 2011. (1 $1^{\text {st }}$ ed. - Iași: H. Goldner, 1876)

\section{B. References}

Acsan, I. (1984). Constelația corifeilor... / The Constellation of the Coryfoi..., Bucureşti: Editura Cartea Românească.

Ameis, K. F. \& Hentze, C. (1965a). Anhang zu Homers Ilias, $4^{\text {th }}$ ed., vol. I-II, Amsterdam: De Gruyter.

Ameis, K. F. \& Hentze, C. (1965b). Anhang zu Homers Odysee, $4^{\text {th }}$ ed., vol. I-II, Amsterdam: De Gruyter.

Aristotel (1965). Poetica, translation by D. M. Pippidi, Bucureşti: Editura Academiei.

Bailly, C.A. (1950). Dictionnaire grec-français, Paris: Hachette.

Barbu, N.I.; \& Piatkowski, A. (1978). Scriitori greci şi latini / Greek and Latin Writers, Bucureşti: Editura Ştiințifică şi Enciclopedică.

Bârlea, P.Gh. (2008). Limba poveştilor populare româneşti / The Language of Romanian Fairytales, Bucureşti: Editura Academiei Române.

Bârlea, P. Gh. (2014). Româna literară în fața poemelor homerice / Literary Romania Face to Face with the Homeric Poems, in: Bârlea, P. Gh. \& Toma, F. R. (coord.), Cultură și comunicare, Editura Muzeul Literaturii Române, Bucureşti, p. $27-31$.

Bârlea, P. Gh. (2015a). Autohtonizarea textelor homerice in versiunile sud-est europene / The Naturalisation of the Homeric Texts in the South-East European Versions, în: Spăriosu, L. \& Popovici, V. (coord.), Communication, Culture, Creation: New Scientific Paradigms, Novi Sad/Arad: Europa Press, p. 23-37.

Bârlea, P.Gh. (2015b). Ipostaze ale homerismului in literatura universală / Hypostases of the Homeric Problem in World Literature, in „Litere”, XVI, 3, (180), p. 67-69.

Camps, W.A. (1980). An Introduction to Homer, Oxford: University Press.

Chantraine, P. (2009). Dictionnaire étymologique de la langue grecque. Histoire des mots, vol. I-II, Paris: Klincksieck.

Foucault, M. (1998). Ordinea discursului. Un discurs despre discurs / The Order of Discourse. A Discourse on Discourse, translation by Ciprian Tudor, București: Eurosong \& Book.

Georgescu, N. (2005). Homer - contemporanulnostru / Homer-Our Contemporary, in: Recife. Eseuri de oceanografie, Bucureşti: Editura „Floare Albastră”, p. 11-51.

Herescu, N.I. (2011). Destin fără moarte (Pentru clasicism) / Immortal Destiny (For Classicism), edition, note on the collection, note on the edition, introductory study by L. Franga, Bucureşti: Editura Muzeul Literaturii Române.

Kirk, G. (coord.) (1985-1993). The Iliad: A Commentary, vol. I-VI, Cambridge: University Press, CrossRef.

Lascu, N. (1974). Clasicii anticii în România / The Ancient Classics in Romania, Cluj-Napoca: Editura Dacia.

Lord, A. (1960). The Singer of Tales, Cambridge, MA: Harvard University Press.

Lovinescu, E. (2012). O privire asupra clasicismului / A Perspective on Classicism, edition supervised, introductory study, note on the edition, notes and commentaries by P. Gh. Bârlea, Bucureşti: Editura Muzeul Literaturii Române. 
Marinescu-Himu, M. \& Piatkowski, A. (1972). Istoria literaturii eline, Bucureşti: Editura Ştiinţifică.

Meister, K. (1966). Die homerische Kunstsprache, $2^{\text {nd }}$ ed., Darmstadt/Leipzig: Teubner Verlag, CrossRef.

Parry, M. (1971). The Making of Homeric Verse, in: The Collected Papers of Milman Parry by Adam M. Parry, Oxford: University Press.

Platon (1983). Opere, vol. IV, edition supervised by P. Creția, București: Editura Științifică și Enciclopedică.

Risch, E. (1973), Wortbildung der homerischen Sprache, $2^{\text {nd }}$ ed., Berlin/New York: De Gruyter \& Co., Tome II: Syntaxe (1997), CrossRef.

Wace, A.J.B. \& Stubbings, F. H. (1963). A Companion to Homer, London/Toronto: Macmillan \& Co..

Whitman, C.H. (1958). Homer and the Homeric Tradition, Cambridge, MA: Harvard University Press. 